American J. of Engineering and Applied Sciences 3 (1): 90-97, 2010

ISSN 1941-7020

(C) 2010 Science Publications

\title{
Fuel and Greenhouse Gas Emission Reduction Potentials by Appropriate Fuel Switching and Technology Improvement in the Canadian Electricity Generation Sector
}

\author{
Farshid Zabihian and Alan S. Fung \\ Department of Mechanical and Industrial Engineering, Ryerson University, \\ 350 Victoria Street, Toronto, Ontario, M5B 2K3, Canada
}

\begin{abstract}
Problem statement: In recent years, Greenhouse Gas (GHG) emissions and their potential effects on global climate change have been a worldwide concern. According to International Energy Agency (IEA), power generation contributes more than half of the global GHG emissions. Approach: Purpose of this study is to examine GHG emission reduction potentials in the Canadian electricity generation sector through fuel switching and adoption of advanced power generation systems. To achieve this objective, eight different scenarios were introduced. In the first scenario, existing power stations' fuel was switched to natural gas. Existing power plants were replaced by Natural Gas Combined Cycle (NGCC), Integrated Gasification Combined Cycle (IGCC), Solid Oxide Fuel Cell (SOFC), hybrid SOFC and SOFC-IGCC hybrid power stations in scenario numbers 2 to 6 , respectively. In last two scenarios, $\mathrm{CO}_{2}$ capture systems were installed in the existing power plants and in the second scenario, respectively. Results: The results showed that Canada's GHG emissions can be reduced by $33,59,20,64,69,29,86$ and $94 \%$ based on the first to eighth scenarios, respectively. On the other hand, the second scenario is the most practical and its technology has already matured and is available. In this scenario by replacing existing power plants by NGCC power plants, Canada can fulfill more than $25 \%$ of its $238,000 \mathrm{kt} \mathrm{year}^{-1}$ commitment of GHG emission reduction to the Kyoto Protocol. In addition, the GHG emission reduction potentials for each province and Canada as a whole were presented and compared. Based on the results, Alberta, Ontario and Saskatchewan are the biggest producers of GHG in Canada by emitting 49, 21 and 14\% of Canada's GHG emissions, respectively. Therefore, they have higher potential to reduce GHG emissions. The comparison of the results for different provinces revealed that based on efficiency of electricity generation and consumed fuel distribution; specific scenario(s) tend to be suitable for each province. Conclusion: The results pointed out that despite of acceptable performance of some provinces, there are still great potentials to reduce GHG emission level in Canada. In addition, the economical analysis showed that some scenarios are economically competitive with current technologies and should be considered when a new power station is to be built.
\end{abstract}

Key words: Greenhouse gases, GHG, reduction potentials, electricity generation, Canada

\section{INTRODUCTION}

Global climate deterioration is a global concern that is caused by high level of Greenhouse Gases (GHGs) in the atmosphere (IPCC, 2007). To address this challenge, in 1992 in Rio de Janeiro and 1997 in Kyoto, there were two major United Nations conferences to reduce GHG emissions in the world. The results of these conferences were international environmental treaties known as United Nations Framework Convention on Climate Change (UNFCCC or FCCC) and Kyoto protocol, respectively. The Kyoto
Protocol is an agreement to reduce GHG emissions of certain countries (Annex I Parties) to specified levels below their 1990 emission levels by available options. This target level for Canada is to reduce GHG emissions to $6 \%$ below 1990 level by the period between 2008 and 2012 (UNFCCC, 1998). The protocol became formally binding on February 16, 2005 and as of August 26, 2009, 188 countries as well as European Union accepted the protocol, covering about $64 \%$ of the emissions addressed by the Protocol (UNFCCC, 2009).

Corresponding Author: Farshid Zabihian, Department of Mechanical and Industrial Engineering, Ryerson University 350 Victoria Street, Toronto, Ontario, M5B 2K3, Canada Tel: 1-416-979-5000/Ext. 7833 Fax: 1-416-979-5265 
Am. J. Engg. \& Applied Sci., 3 (1): 90-97, 2010

Table 1: Electricity generation in Canada for different types of consumed fuels in 2006 (International Energy Agency, 2009)

\begin{tabular}{lcc}
\hline Fuel type & Generated electricity $(\mathrm{GWh})$ & Percent \\
\hline Hydro & 314,230 & 58.4 \\
Coal & 95,050 & 17.6 \\
Nuclear & 92,420 & 17.2 \\
Natural gas & 25,780 & 4.8 \\
Refined petroleum products & 5,140 & 1.0 \\
Renewable & 3,770 & 0.7 \\
Other & 1,870 & 0.3 \\
\hline
\end{tabular}

The objectives of this study are to introduce and evaluate several scenarios to reduce GHG emissions by fuel switching and adoption of advanced power systems in Canadian electricity generation industry.

Current status of GHG emissions in power generation industry: According to the World Energy Outlook published by the International Energy Agency (IEA), the world's total net electricity consumption will increase dramatically. The world electricity generation was 14,781 billion $\mathrm{kWh}$ in 2003 and will increase to 21,699 and 30,116 billion $\mathrm{kWh}$ in 2015 and 2030, respectively (International Energy Agency, 2006).

The same report predicted that the share of fossil fuels as energy supplies for electricity generation would remain constant at nearly $65 \%$. Also, GHG emissions from energy industry will increase by 55\% between 2004 and 2030. In this period, coal and oil are leading contributors to global energy-related $\mathrm{CO}_{2}$ emission (International Energy Agency, 2006). It has been shown that more than half of the $\mathrm{CO}_{2}$ emission of industrial large point sources is from power production industry (Gale, 2005).

According to the Canada's Energy Outlook published by Natural Resources Canada, electricity consumption in Canada will increase to 593 TWh by 2020, growing at average rate of $1.2 \%$ annually. However, the GHG emissions of electricity generation industry will increase slightly, from $130 \mathrm{Mt}$ in 2004 to $131 \mathrm{Mt}$ in 2010 (Natural Resources Canada, 2006).

Table 1 shows the status of Canadian electricity generation sector based on type of consumed fuels for electricity generation (Environment Canada, 2008).

These statistics show that electricity generation sector is and will remain a major source of GHG emissions and it is essential to reduce these emissions.

\section{MATERIALS AND METHODS}

Different methodologies to calculate GHG emissions: In this study the "2006 IPCC Guidelines for National Greenhouse Gas Inventories (Eggleston et al., 2006)" will be used to provide methodologies for estimating GHG emissions.
Table 2: Default emission factors used in Tier 1 ( $\mathrm{kg}$ of GHG per TJ on a net calorific basis) (Eggleston et al., 2006)

\begin{tabular}{llcl}
\hline Fuel type & $\mathrm{CO}_{2}$ & $\mathrm{CH}_{4}$ & $\mathrm{~N}_{2} \mathrm{O}$ \\
\hline Natural gas & 56,100 & 5 & 0.1 \\
Diesel oil & 74,100 & 10 & 0.6 \\
Residual oil & 77,400 & 10 & 0.6 \\
\hline
\end{tabular}

Table 3: Default emission factors used in the Tier $3\left(\mathrm{~kg} \mathrm{TJ}^{-1}\right)$ (Eggleston et al., 2006)

\begin{tabular}{lcc}
\hline Fuel and technology type & $\mathrm{CH}_{4}$ & $\mathrm{~N}_{2} \mathrm{O}$ \\
\hline Natural gas & 1.0 & 1.0 \\
Boilers & 4.0 & 1.0 \\
Gas-fired gas turbines (>3 MW) & 3.0 \\
Combined cycle & 1.0 & \\
Gas/diesel oil & 0.9 & 0.4 \\
Boilers & & 0.3 \\
Residual oil & 0.8 & \\
Residual fuel oil normal firing &
\end{tabular}

Generally, emission of each GHG is estimated by multiplying fuel consumption by the corresponding emission factor.

There are three tiers presented in the 2006 IPCC Guidelines for estimating emissions from fossil fuel combustion for electricity generation. In these tiers, fuel consumption and emission factors are considered as follows (Eggleston et al., 2006):

- Tier 1: Tier 1 is a fuel-based method to estimate GHG emissions. In this tier, the quantities of consumed fuel and average emission factors for all relevant direct greenhouse gases are used for GHG analysis. The Tier 1 emission factors are available in IPCC guidelines. Table 2 shows default emission factors for three fuels (Eggleston et al., 2006)

- Tier 2: In Tier 2, similar to Tier 1, the quantities of consumed fuel from fuel statistics are used to estimate GHG emissions. But instead of the Tier 1 default emission factors, country specific emission factors are used

- Tier 3: Tier 1 and 2 approaches of estimating GHG emissions necessitate using an average emission factors, either default emission factors in Tier 1 or country specific emission factors in Tier 2 . In reality, GHG emissions depend upon the fuel type, combustion technology, operating conditions, control technology, quality of maintenance and age of the equipments. In Tier 3 approach, these parameters are taken into account by using different emission factors for each case (Table 3 (Eggleston et al., 2006)). The emission of $\mathrm{CO}_{2}$ highly depends on the carbon content of the fuel. Therefore, the $\mathrm{CO}_{2}$ emission factors from Table 2 are sufficient for this tier 
Am. J. Engg. \& Applied Sci., 3 (1): 90-97, 2010

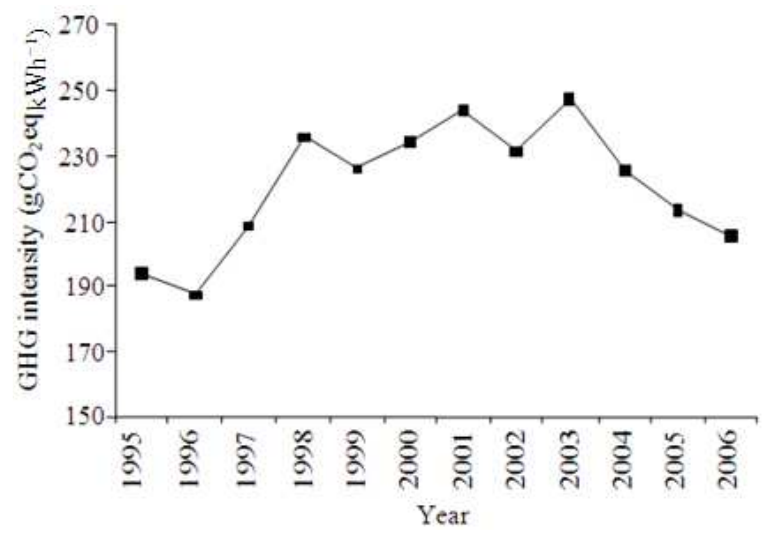

Fig. 1: Average GHG intensity in Canada's electricity generation sector between 1995 and 2005 (Eggleston et al., 2006)

All these tiers use the amount of fuel combusted as the activity data. In the energy sector, the activity data are typically the fuel consumption to generate electricity. These data are sufficient for the Tier 1 analysis. In higher tier approaches, additional data are required on fuel characteristics and power generation technologies.

Being one of the Annex I Parties, Canada's annual national greenhouse gas inventory report has been prepared and published by Environment Canada. The calculations of GHG emissions for Canadian electricity generation industry in this study are based on Tier 3 with country specific emission factors and activity data is provided by Environment Canada (2008).

Figure 1 illustrates average GHG intensity in Canada's electricity generation sector between 1995 and 2005 (Environment Canada, 2008). According to the graph, Canada experienced $6 \%$ increase in average GHG intensity in this period. In this graph, greenhouse gas intensity is the ratio of GHG emissions to generated electricity. This parameter is used to evaluate the electricity generation performance in terms of GHG emissions.

This indicates that there are great potentials for GHG intensity reduction in the sector. In the rest of this study, some of these potentials will be discussed.

GHG emission reduction scenarios: Despite the problems in fossil fuel-fired power plants, fossil fuels are available on a mid and long-term basis and their continued large-scale and widespread applications in power generation industry are essential in order to maintain current economic growth in the world. The IEA has commented that "numerous technology solutions offer substantial $\mathrm{CO}_{2}$ reduction potentials, including renewable energies, higher efficiency power generation, fossil-fuel use with $\mathrm{CO}_{2}$ capture and storage, nuclear fission, fusion energy, hydrogen, biofuels, fuel cells and efficient energy end use. No single technology can meet this challenge by itself. Different regions and countries will require different combinations of technologies to best serve their needs and best exploit their indigenous resources. The energy systems of tomorrow will rely on a mix of different advanced, clean, efficient technologies for energy supply and use" (International Energy Agency, 2009).

Thus, both fossil and non-fossil sources of energy will be needed in the foreseeable future to meet global energy demands. It is, therefore, important that alternative technologies are commercialized to permit the consumption of fossil fuels with significantly reduced GHG emissions and other pollutants.

Based on this, different scenarios to reduce GHG emissions are defined as follows:

Scenario number 1: In this scenario, GHG emission reduction potentials by fuel switching will be investigated. Based on this scenario, all power plants will use natural gas as primary fuel. But technology of power stations will remain unchanged.

Scenario number 2: In the second scenario, there will be fuel switching as well as technology changes. According to this scenario, all power stations will be replaced by Natural Gas Combined Cycle (NGCC). The size of the alternative NGCC power plant is $505 \mathrm{MW}$. The plant configuration consists of two gas turbines, a heat recovery steam generator, and a condensing reheat steam turbine. In this study, the efficiency of the power plant is considered to be $49 \%$ (based on higher heating value, HHV) (Spath and Mann, 2000).

Scenario number 3: In this scenario, it is assumed that all existing coal-fired power stations are replaced by Integrated Gasification Combined Cycle (IGCC). In IGCC technology, gas turbine and steam cycle are incorporated with modern coal gasification plant to use coal for electricity generation with greatly improved efficiency and environmental performance. This technology's advantages can be summarized as their greater than $40 \%$ thermal efficiency, high fuel flexibility and very low pollutant emissions. The efficiency of IGCC is considered to be $43 \%$ (Topper, 2006) (HHV) in this study.

Scenario numbers 4 and 5: In order to implement these scenarios, all existing power stations will be replaced by Solid Oxide Fuel Cell (SOFC) for the 
fourth scenario and hybrid SOFC power plants for the fifth scenario. In both cases power plants will be fueled by natural gas.

Fuel cells operation is based on direct and continuous conversion of fuel chemical energy into electrical energy in electrochemical process. Because of this direct energy conversion, their efficiencies are usually higher than conventional electricity generation technologies.

Fuel cells can be classified by their operating temperature and electrolyte compositions, which dictate their suitability for different applications. SOFCs have high operating temperature (between $600-1000^{\circ} \mathrm{C}$ ) which makes them especially suited for stationary power generation, also allowing for internal reforming of different fuels within the cells.

There are numerous demonstrational and semicommercial units of SOFCs installed around the world with different sizes and configurations (Singhal and Kendall, 2006; Singhal, 2002; Williams et al., 2006). But so far, to the authors' best knowledge, there have been three proof-of-concept SOFC hybrid power plants installed in the world (Veyo et al., 2002; Mitsubishi Heavy Industries, Ltd., 2009).

Since these technologies have not been commercialized yet, there are no universally accepted efficiency ranges for them. However, for SOFC power generation units, efficiency of 50 to $60 \%$ has been reported (Petruzzi et al., 2003; Campanari, 2001). In the case of the SOFC hybrid cycle, the efficiency is higher and its range is wider, from $57 \%$ to more than $75 \%$ (Calise et al., 2006; Palsson et al., 2002; Song et al., 2005). For this study the average efficiencies of 55\% for the fourth scenario and $65 \%$ for the fifth scenario are considered.

Scenario number 6: This scenario is a combination of the third and fourth scenario. In this case, all existing coal-fired power stations will be replaced by SOFC and IGCC hybrid cycles. The efficiency of cycle is considered to be 50\% (Kuchonthara et al., 2005; Jansen et al., 1994).

Scenario numbers 7 and 8: $\mathrm{CO}_{2}$ Capture and Storage (CCS) systems are technologies that can be used to reduce $\mathrm{CO}_{2}$ emission by different industries where combustion is part of the process. A major problem of CCS utilization is their high efficiency penalty in power plants (Metz, 2005).

In the seventh scenario, CCS is installed in the existing power plants with current technologies. For the last scenario, all existing power plants will be replaced by NGCC plants equipped with $\mathrm{CO}_{2}$ capture system. The CCS system in these scenarios is capable of removing $90 \%$ of $\mathrm{CO}_{2}$ from flue gas but because of consumption of more fuel to compensate plants efficiency reduction, overall, $87 \%$ of $\mathrm{CO}_{2}$ can be captured. The output penalty of $10 \%$ is considered for both scenarios.

\section{RESULTS}

GHG emission reduction potentials in Canada: Table 4 shows different fuels consumption, electricity production for each fuel and GHG emissions for current situation and eight GHG emission reduction scenarios and reduction potentials as well as GHG intensity for each scenario in Canadian fossil fuel-fired thermal power plants.

In order to perform these calculations, the fuel consumption, electricity production and emission factors for different fuels for each province were used to estimate GHG emission reduction potentials. The latest data publicly available from Environment Canada that has been used in this study is for 1996 (Environment Canada, 2006).

It should be noted that the focus of this study is on GHG emission reduction potentials in fossil fuel-fired thermal power plants. Therefore, other power generation technologies (such as, nuclear, hydro and renewables) are not considered in the estimation of GHG emissions.

Table 4 shows that Canada's GHG emissions can be reduced from almost $100 \mathrm{Mt}$ year $^{-1}$ in the base case (existing case) to $65,40,79,36,30,70,14$ and $6 \mathrm{Mt}$ year $^{-1}$ based on the first to eighth scenarios, respectively. This means 33, 59, 20, 64, 69, 29, 86 and 94\% reduction potentials in GHG emissions, respectively.

The best solutions are the eighth, seventh and fifth scenarios, respectively. On the other hand, the second scenario is the most practical one and its technology has already matured and is available. This scenario can reduce GHG emissions by almost $60 \%$. This means that just by replacing existing thermal power plants by NGCC plants Canada can fulfill more than $25 \%$ of its $238 \mathrm{Mt}$ year $^{-1}$ commitment of GHG emission reduction to Kyoto Protocol (Environment Canada, 2005) (Fig. 2).

Table 5 shows the summary of results for some provinces including Alberta, Ontario, Saskatchewan, Nova Scotia, New Brunswick, British Columbia, Newfoundland and Canada as a whole. Other provinces are not included since they, together, are responsible for only approximately $1 \%$ of Canada's GHG emissions from electricity generation. Based on Table 5, Alberta, Ontario and Saskatchewan are the biggest producers of GHG in Canada's electricity generation sector by emitting 49, 21 and $14 \%$ of this sector's GHG emissions, respectively. Therefore, they have higher potentials to reduce GHG emissions. 
Am. J. Engg. \& Applied Sci., 3 (1): 90-97, 2010

Table 4: Fuel consumption, electricity production, GHG emission reduction potentials and intensity in Canada

\begin{tabular}{|c|c|c|c|c|c|c|c|c|c|c|}
\hline & Fuel & Existing & Scenario 1 & Scenario 2 & Scenario 3 & Scenario 4 & Scenario 5 & Scenario 6 & Scenario 7 & Scenario 8 \\
\hline \multirow{3}{*}{$\begin{array}{l}\text { Fuel } \\
\text { consumption }\end{array}$} & Coal (kt) & 46,927 & 0 & 0 & 35,259 & 0 & 0 & 30,322 & 51,620 & 0 \\
\hline & Petroleum (ML) & 1,692 & 0 & 0 & 1,692 & 0 & 0 & 1,692 & 1,861 & 0 \\
\hline & Natural gas (BL) & 4,061 & 34,690 & 21,368 & 4,061 & 18,960 & 16,043 & 4,061 & 4467 & 23,505 \\
\hline \multirow{4}{*}{$\begin{array}{l}\text { Electricity } \\
\text { production } \\
(\mathrm{GWh})\end{array}$} & Coal & 86,150 & 0 & 0 & 86,150 & 0 & 0 & 86,150 & 86,150 & 0 \\
\hline & Petroleum & 7,115 & 0 & 0 & 7,115 & 0 & 0 & 7,115 & 7,115 & 0 \\
\hline & Natural gas & 14,577 & 107,841 & 107,841 & 14,577 & 107,841 & 107,841 & 14,577 & 14,577 & 107,841 \\
\hline & Total & 107,841 & 107,841 & 107,841 & 107,841 & 107,841 & 107,841 & 107,841 & 107,841 & 107,841 \\
\hline \multirow{4}{*}{$\begin{array}{l}\text { GHG } \\
\text { emissions } \\
\left(\text { kt year }^{-1}\right)\end{array}$} & Coal & 85,421 & 0 & 0 & 66,147 & 0 & 0 & 56,886 & 12,215 & 0 \\
\hline & Petroleum & 5,202 & 0 & 0 & 5,202 & 0 & 0 & 5,202 & 744 & 0 \\
\hline & Natural gas & 7,662 & 65,436 & 40,138 & 7,662 & 35,609 & 30,131 & 7,662 & 1,096 & 5,740 \\
\hline & Total & 98,285 & 65,436 & 40,138 & 79,011 & 35,609 & 30,131 & 69,750 & 14,055 & 5,740 \\
\hline \multirow{4}{*}{$\begin{array}{l}\text { Reduction } \\
\text { potential (\%) }\end{array}$} & Coal & - & - & - & 23 & - & - & 33 & 86 & - \\
\hline & Petroleum & - & - & - & 0 & - & - & 0 & 86 & - \\
\hline & Natural gas & - & 33 & 59 & 0 & 64 & 69 & 0 & 86 & 94 \\
\hline & Total & - & 33 & 59 & 20 & 64 & 69 & 29 & 86 & 94 \\
\hline $\begin{array}{l}\text { GHG intensity } \\
\left(\mathrm{gCO}_{2} \mathrm{eq} \mathrm{kWh}^{-1}\right)\end{array}$ & Total & 911 & 607 & 372 & 733 & 330 & 279 & 647 & 130 & 53 \\
\hline
\end{tabular}

Table 5: The GHG emissions and reduction potentials for each scenario in different provinces in Canada

\begin{tabular}{|c|c|c|c|c|c|c|c|c|c|}
\hline & \multirow{2}{*}{$\begin{array}{l}\text { Existing } \\
\text { GHG emissions } \\
\left(\text { kt year }^{-1}\right)\end{array}$} & \multicolumn{2}{|l|}{ Scenario 1} & \multicolumn{2}{|l|}{ Scenario 2} & \multicolumn{2}{|l|}{ Scenario 3} & \multicolumn{2}{|l|}{ Scenario 4} \\
\hline & & $\begin{array}{l}\text { GHG emissions } \\
\left(\mathrm{kt} \mathrm{year}^{-1}\right)\end{array}$ & $\begin{array}{l}\text { Reduction } \\
\text { potential }(\%)\end{array}$ & $\begin{array}{l}\text { GHG emissions } \\
\left(\text { kt year }^{-1}\right)\end{array}$ & $\begin{array}{l}\text { Reduction } \\
\text { potential }(\%)\end{array}$ & $\begin{array}{l}\text { GHG emissions } \\
\left(\mathrm{kt} \mathrm{year}^{-1}\right)\end{array}$ & $\begin{array}{l}\text { Reduction } \\
\text { Potential \% }\end{array}$ & $\begin{array}{l}\text { GHG emissions } \\
\left(\mathrm{kt} \mathrm{year}^{-1}\right)\end{array}$ & $\begin{array}{l}\text { Reduction } \\
\text { potential }(\%)\end{array}$ \\
\hline$\overline{\text { Canada }}$ & 98,285 & 65,436 & 33 & 40,138 & 59 & 79,011 & 20 & 35,609 & 64 \\
\hline Alberta & 48,070 & 31,870 & 33 & 18,200 & 62 & 37,368 & 22 & 16,146 & 66 \\
\hline Ontario & 20,784 & 13,590 & 35 & 10,710 & 48 & 19,978 & 4 & 9,501 & 54 \\
\hline Saskatchewan & 13,661 & 9,517 & 30 & 3,486 & 74 & 7,482 & 45 & 3,092 & 77 \\
\hline Nova Scotia & 7,282 & 4,675 & 36 & 3,304 & 55 & 6,260 & 14 & 2,931 & 60 \\
\hline New Brunswick & 6,055 & 3,716 & 39 & 2,627 & 57 & 5,491 & 9 & 2,330 & 62 \\
\hline British Columbia & 1,277 & 1,286 & - & 1,260 & 1.5 & 1,277 & - & 1,117 & 12 \\
\hline \multirow[t]{2}{*}{ Newfoundland } & 1,155 & 782 & 32 & 552 & 52 & 1,155 & - & 490 & 58 \\
\hline & & \multicolumn{2}{|l|}{ Scenario 5} & \multicolumn{2}{|l|}{ Scenario 6} & \multicolumn{2}{|l|}{ Scenario 7} & \multicolumn{2}{|l|}{ Scenario 8} \\
\hline Canada & 98,285 & 30,131 & 69 & 69,750 & 29 & 14,055 & 86 & 5,740 & 94 \\
\hline Alberta & 48,070 & 13,662 & 72 & 32,529 & 32 & 6,874 & 86 & 2,603 & 95 \\
\hline Ontario & 20,784 & 8,040 & 61 & 17,712 & 15 & 2,972 & 86 & 1,532 & 93 \\
\hline Saskatchewan & 13,661 & 2,617 & 81 & 6,504 & 52 & 1,954 & 86 & 498 & 97 \\
\hline Nova Scotia & 7,282 & 2,480 & 66 & 5,475 & 25 & 1,041 & 86 & 472 & 94 \\
\hline New Brunswick & 6,055 & 1,972 & 67 & 5,099 & 16 & 866 & 86 & 376 & 94 \\
\hline British Columbia & 1,277 & 946 & 26 & 1,277 & - & 183 & 86 & 180 & 86 \\
\hline Newfoundland & 1,155 & 415 & 64 & 1,155 & - & 165 & 86 & 79 & 93 \\
\hline
\end{tabular}

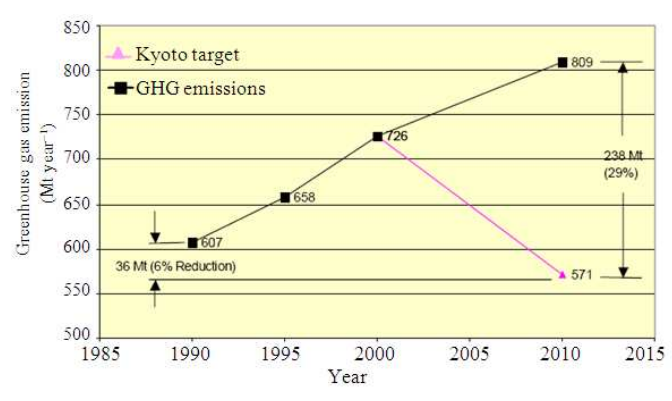

Fig. 2: Canada GHG projection and Kyoto Protocol (Environment Canada, 2005)

In Ontario, for the first scenario (fuel switching to natural gas) there is a $35 \%$ reduction potential which is slightly higher than the national average of $33 \%$. For the second, fourth and fifth scenarios, GHG reduction potentials in Ontario are considerably lower than Canadian average with 48,54 and $61 \%$ in comparison with 59, 64 and 69\%, respectively. This could be as a result of high efficiency of both natural gas and coal fueled power stations in Ontario.

The same is true for the third and sixth scenarios where Ontario's GHG emission reduction potentials, 4 and $15 \%$, are significantly lower than national average of 20 and $29 \%$, respectively.

For Ontario, it can be concluded that although power generation sector is emitting less GHG in comparison to national average, there are still considerable potentials under these eight scenarios. In addition, the first scenario tends to be the most suitable scenario in short term. 
Furthermore, the results point out that the level of GHG emission reduction potentials depends on the share of coal in electricity generation. For instance, share of coal in electricity generation from fossil fuel in Alberta, Ontario and Saskatchewan are 87, 70 and 92\%, respectively, during the same period (Environment Canada, 2008). Accordingly, results show that Saskatchewan, Alberta and Ontario have the highest level of GHG emission reduction potentials, respectively, especially for the third and sixth scenarios.

\section{DISCUSSION}

Cost of different scenarios: Inevitably, the first question raises about these scenarios is their impacts from economic point of view. The cost of the first scenario is not considerable and the main issue is availability of natural gas at reasonable price.

Since scenario numbers 4,5 and 6 are not commercialized yet, it is not possible to assess their cost accurately. Therefore, in this study, economic effects of scenario numbers $2,3,7$ and 8 will be investigated mostly based on Rubin et al. (2007).

Investigation of different economical studies (Metz, 2005; Rubin et al., 2007; Rao and Rubin, 2002) revealed considerable variation in costs of power generation and $\mathrm{CO}_{2}$ capture unit, both capital cost and Cost Of Electricity (COE), for all types of power plants due to different assumptions about key parameters, such as fuel properties, fuel cost, plant size, plant efficiency, plant capacity factor, plant financing, and performance of the $\mathrm{CO}_{2}$ capture unit (Rubin et al., 2007).

The general conclusion from studies published prior to 2004 is that the $\mathrm{COE}$, for both configurations with and without $\mathrm{CO}_{2}$ capture, is the lowest for NGCC plants. For coal-based plants, Pulverized Fuel-fired (PF) for configuration without $\mathrm{CO}_{2}$ capture and IGCC plants for configuration with $\mathrm{CO}_{2}$ capture have the lowest $\mathrm{COE}$.

More recent studies showed different pattern because of increase in price of several items (Rubin et al., 2007). They showed that PF and IGCC have the lowest COE for configurations without and with $\mathrm{CO}_{2}$ capture system, respectively. These results were not in agreement with the studies prior to 2004. The reason is that in recent years, the price of natural gas $(\$ 3-4.5 / \mathrm{GJ}$ in studies prior to 2004 vs. $\$ 6 / G J$ in studies after 2004) as well as many raw materials has increased significantly.

In order to have a clear idea of natural gas price variations, Fig. 3 shows natural gas price in Canadian \$/GJ in Canadian market (Energyshop, 2009). As the graph indicates, although $\$ 6 / G J$ is not reflecting the current price of natural gas, it is more reasonable than $\$ 3-4.5 / G J$.

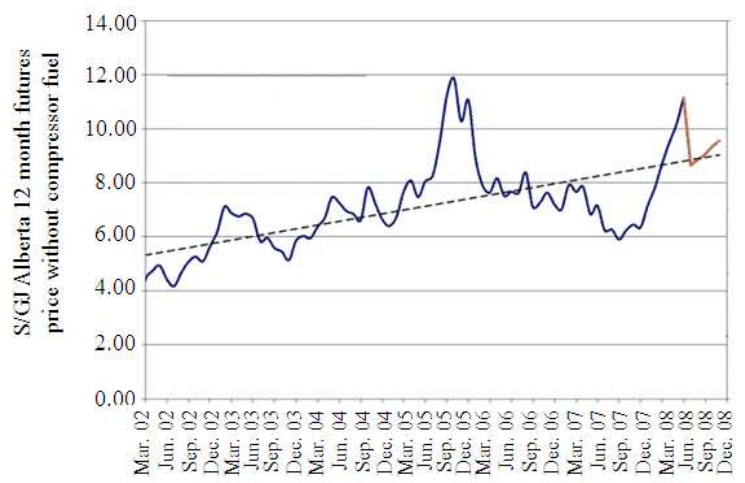

Fig. 3: Natural gas prices in Canadian market (Energyshop, 2009)

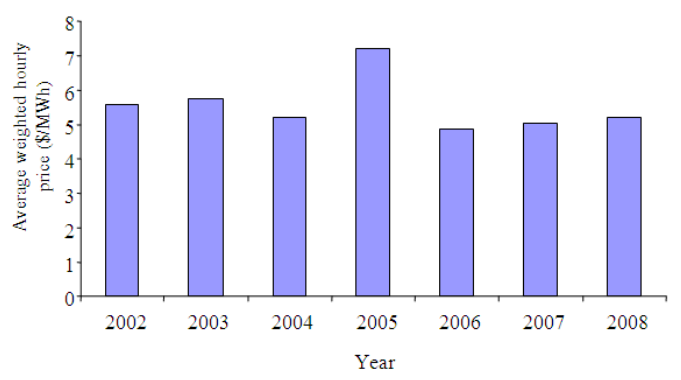

Fig. 4: Annual average weighted prices of electricity reported by Independent Electricity System Operator (IESO) for Ontario, Canada between 2002 and 2008 (Independent Electricity System Operator, 2009)

Moreover, the COEs reported in these studies are comparable with annual average weighted prices of electricity shown in Fig. 4, reported by Independent Electricity System Operator (IESO) for Ontario, Canada between 2002 and 2008 (Independent Electricity System Operator, 2009).

In conclusion, scenario numbers 2 and 3 can compete with existing power plants, especially using IGCC technology, when the current increase in natural gas price is considered. Therefore, when a new power station is to be built these technologies should be considered as main candidates. For scenario numbers 7 and $8, \mathrm{CO}_{2}$ capture from power plants is still too expensive but their costs are expected to lower as a consequence of technological improvements.

\section{CONCLUSION}

In this study, the GHG emission reduction potentials were investigated under eight introduced 
scenarios. The results for Canadian power stations showed that there are very high GHG emission reduction potentials. The estimation for GHG emission reduction potentials for different provinces revealed that Alberta, Ontario, and Saskatchewan are responsible for more than $84 \%$ of GHG emissions in the electricity generation sector in Canada. Therefore, they have the highest GHG emission reduction potentials. The results pointed out that despite acceptable performance in some provinces, there are considerable potentials to reduce GHG emissions. For instance, the second scenario, being the most practical scenario in Canada, can reduce GHG emissions by almost $60 \%$, which is more than $25 \%$ of Canada's commitment of GHG emission reduction to Kyoto Protocol.

The economic analysis showed that when a new power station is to be built, different scenarios should be considered, particularly scenario numbers 2 and 3 , because they can compete with existing power plants in terms of cost. Furthermore, $\mathrm{CO}_{2}$ capture from power plants is still too expensive but their costs are expected to decrease.

\section{ACKNOWLEDGEMENT}

The authors gratefully acknowledge the financial support provided by the Natural Sciences and Engineering Research Council of Canada (NSERC) through the Discovery Grants (DG).

\section{REFERENCES}

Campanari, S., 2001. Thermodynamic model and parametric analysis of a tubular SOFC module. J. Power Sour., 92: 26-34. DOI: 10.1016/S03787753(00)004 94-8

Calise, F., M. Dentice d'Accadia, A. Palombo and L. Vanoli, 2006. Simulation and energy analysis of a hybrid Solid Oxide Fuel Cell (SOFC)-gas turbine system. Energy, 31: 3278-3299. $\quad$ DOI: 10.1016/j.energy.2006.03.006

Eggleston, H.S., L. Buendia, K. Miwa, T. Ngara and K. Tanabe, 2006. IPCC guidelines for national greenhouse gas inventories. Intergovernmental Panel on Climate Change (IPCC).

http://www.ipcc-

nggip.iges.or.jp/public/2006gl/pdf/0_Overview/V0 _0_Cover.pdf

Energyshop, 2009. Natural gas prices-historical and forecast.

http://www.energyshop.com/es/homes/gas/gasprice forecast.cfm?r
Environment Canada, 2005. National inventory report 1990-2003: Greenhouse gas sources and sinks in Canada.

http://www.ec.gc.ca/pdb/ghg/inventory_report/200 3_report/2003_report_e.pdf

Environment Canada, 2006. National inventory report 1990-2004: Greenhouse Gas sources and sinks in Canada.

http://www.ec.gc.ca/pdb/ghg/inventory_report/200 4_report/2004_report_e.pdf

Environment Canada, 2008. National inventory report 1990-2006: Greenhouse gas sources and sinks in Canada.

http://www.ec.gc.ca/pdb/ghg/inventory_report/200 6_report/2006_report_e.pdf

Gale, J., 2004. Geological storage of $\mathrm{CO}_{2}$ : What do we know, where are the gaps and what more needs to be done? Energy, 29: 1329-1338. DOI: 10.1016/j.energy.2004.03.068

Independent Electricity System Operator, 2009. Monthly market update.

http://www.theimo.com/imoweb/siteShared/monthl y_prices.asp?sid=ic

International Energy Agency, 2006. World energy outlook 2006.

http://www.iea.org/textbase/nppdf/free/2006/weo2 006.pdf

International Energy Agency, 2009. Energy technology: Facing the climate challenge. http://www.gbltrends.com/doc/challenge\%20EAI.pdf

IPCC., 2007. Synthesis report, summary for policymakers. http://www.ipcc.ch/pdf/assessmentreport/ar4/syr/ar4_syr_spm.pdf

Jansen, D., P.C. van der Laag, A.B.J. Oudhuis and J.S. Ribberink, 1994. Prospects for advanced coalfuelled fuel cell power plants. J. Power Sour., 49: 151-165. DOI: 10.1016/0378-7753(93)01807-T

Kuchonthara, P., S. Bhattacharya and A. Tsutsumi, 2005. Combination of thermochemical recuperative coal gasification cycle and fuel cell for power generation. Fuel, 84: 1019-1021. DOI: 10.1016/j.fuel.2004.08.024

Metz, B., 2005. IPCC Special Report on Carbon Dioxide Capture and Storage. Cambridge University Press, Cambridge, ISBN: 052186643X, pp: 431.

Mitsubishi Heavy Industries, Ltd., 2009. MHI achieves 3,000-hour operation, unprecedented in Japan of SOFC-MGT combined-cycle power generation system.

http://www.mhi.co.jp/en/news/story/0910011315.html 
Natural Resources Canada, 2006. Canada's energy outlook: The reference case. http://www.nrcanrncan.gc.ca/inter/pdf/outlook2006_e.pdf

Palsson, J., A. Selimovic and L. Sjunnesson, 2000. Combined solid oxide fuel cell and gas turbine systems for efficient power and heat generation. J. Power Sour., 86: 442-448. DOI: 10.1016/S03787753(99) 00464-4

Petruzzi, L., S. Cocchi and F. Fineschi, 2003. A global thermo-electrochemical model for SOFC systems design and engineering. J. Power Sour., 118: 96-107. DOI: 10.1016/S0378-7753(03)00067-3

Rao, A.B. and E.S. Rubin, 2002. A technical, economic and environmental assessment of amine-based $\mathrm{CO}_{2}$ capture technology for power plant greenhouse gas control. Environ. Sci. Technol., 36: 4467-4475. DOI: $10.1021 / \mathrm{es} 0158861$

Rubin, E.S., C. Chen and A.B. Rao, 2007. Cost and performance of fossil fuel power plants with $\mathrm{CO}_{2}$ capture and storage. Energy Policy, 35: 4444-4454. DOI: 10.1016/j.enpol. 2007.03.009

Singhal, S.C., 2002. Solid Oxide Fuel Cells for stationary, mobile and military applications. Solid State Ionics, 152-153: 405-410. DOI: 10.1016/S0167-2738(02)00349-1

Singhal, S.C. and K. Kendall, 2006. High Temperature Solid Oxide Fuel Cell, Fundamental, Design and Applications. Elsevier, ISBN-13: 978-1-85617387-2.

Song, T.W., J.L. Sohn, J.H. Kim, T.S. Kim, S.T. Ro and K. Suzuki, 2005. Performance analysis of a tubular solid oxide fuel cell/micro gas turbine hybrid power system based on a quasi-two dimensional model. J. Power Sour., 142: 30-42. DOI: 10.1016/j.jpowsour.2004.10.011

Spath, P.L. and M.K. Mann, 2000. Life cycle assessment of a natural gas combined-cycle power generation system. National Renewable Energy Laboratory (NREL), US Department of Energy Laboratory. http://www.nrel.gov/docs/fy00osti/27715.pdf
Topper, J., 2006. IEA energy technology day coal fired power and efficiency. IEA Clean Coal Centre. http://www.iea.org/work/2006/neet/John_Topper_ CCC.pdf

United Nations Framework Convention on Climate Change, 1998. Kyoto protocol to the United Nations framework convention on climate change. http://unfccc.int/resource/docs/convkp/kpeng.pdf

United Nations Framework Convention on Climate Change, 2009. Kyoto protocol, status of ratification. http://unfccc.int/kyoto_protocol/background/status _of_ratification/items/2613.php

Veyo, S.E., L.A. Shockling, J.T. Dederer, J.E. Gillett and W.L. Lundberg, 2002. Tubular solid oxide fuel cell/gas turbine hybrid cycle power systems: Status. J. Eng. Gas Turbin. Power, 124-4: 845-849. DOI: $10.1115 / 1.1473148$

Williams, M.C., J.P. Strakey, W.A. Surdoval and L.C. Wilson, 2006. Solid oxide fuel cell technology development in the US. Solid State Ionics, 177: 2039-2044. DOI: 10.1016/ j.ssi.2006.02.051 